\title{
Bullying among Javanese Ethnic Senior High School Students
}

\author{
Chr. Argo Widiharto, Padmi Dhyah Yulianti, Sri Wahyuni
}

\begin{abstract}
This study is to find out the type of bullying that often occurs in high school of Javanese ethnic. The Javanese has a strong norm of courtesy, respect for the elder and they cannot speak frankly. In addition, the characteristics of the Javanese are also obedient (setya tuhu), not rejective and not rebellious. Javanese has also apolite language and it always humble. All of these Javanese characters are contrary to bullying which is an aggressive behavior that involves intention to harm others. In this research, the data were collected by using survey through open questionnaire. The data were collected from 7 (seven) cities in Central Java which were selected randomly. The subjects of the research were 287 high school students which were selected by purposive sampling technique. The data was analyzed by using indigenous psychology approach. The result of the study showed that there were 3 types of bullying in high school. They were verbal bullying (mocked, lied and slandered) as much as $72.13 \%$, physical bullying (hit, groped and spit) as much as $14.63 \%$ and psychological bullying (belittled and exiled) as much as $13.24 \%$.
\end{abstract}

Index Terms: Bullying; High School; Javanese Ethnic.

\section{INTRODUCTION}

The term bullying was first used by Olweus which refers to the attack of a stronger child to a weaker child ${ }^{29}$. Olweus (1993) states that in Scandinavia the word mobbing (Norwegian, Danish) is used to refer to bullying or mobbing (Swedish, Filandia). While the original word in English "mob" refers to people who annoy or harass others ${ }^{43}$.

Furthermore, Olweus (1993) explains that students are said to be bullied when they often get negative behavior repeatedly from one or more other students ${ }^{27,28}$. This negative behavior causes other people suffered, injured or uncomfortable. Negative behavior can be in verbal from e.g. threatened, ridiculed or reproached, insinuated and a name calling (dub). Another type of negative behavior includes physical contacts such as hitting someone, pushing, kicking, slapping or curbing with physical contact. While negative behavior other than using words and physical contact is an unpleasant face or body language, alienating and refusing to join a group.

In 1999, Olweus states that bullying has three criteria: (1) there is aggressive behavior or intention to harm, (2) the behavior is repeated and done many times (3) there is an imbalance of power $^{8}$. This definition is more widely accepted by the bullying researchers in the world. This bullying case should be prevented. It will be affected to the victim's mental health. Children and teenagers who were experienced in

Revised Manuscript Received on September 22, 2019.

Chr. Argo Widiharto, Airlangga University Surabaya, Indonesia. argo_widi@yahoo.com

Padmi Dhyah Yulianti, Universitas PGRI Semarang, Indonesia.

Sri Wahyuni, Universitas PGRI Semarang, Indonesia. bullying will be have physical and psychological problems (Nansel, Craig, Overpeck, Saluja, \& Ruan, 2004) and mental health problems such as depression, dismay, committing suicide and hyperactivity ${ }^{7,9,16,24,33,37,50}$

Due to the bullying, victims will withdraw themselves from their peers. Some victims refused to go to school for some time or even quit from school. Solberg \& Olweus (2003) decribe that the victims commontly have low psychosocial adjustment, social disintegration, negative self-evaluation ${ }^{45}$, and sustained depression. In addition, according to Sanders, Cheryl E and Phye (2004), victims will avoid playgrounds at school in order they will not become the victims of bullying anymore $^{34}$.

Salmivalli \& Voeten (2004) states that bullying is relating to the role expectation from the environment ${ }^{32}$.So, a person or group of people who bullies others because they feel that their behavior is based on the environmental expectation. The results of the study conducted by Foshee, Reyes, Vivolo-Kantor, Basile, \& Chang, (2014) ${ }^{15}$ shows that bullying is not ethnic and sex related but Skrzypiec, Slee, Murray-Harvey, \& Pereira (2011) state that handling bullying in Asia should involve a social environment ${ }^{23,41}$. This is different from handling individual bullying in Europe. Bullying arises because the social environment supports for the emergence of these behaviors and bullying is perceived as a natural thing. Indonesia as part of a country in Asia also has bullying problems as well as countries in Europe or some other countries in Asia.

Several bullying studies have been conducted in Indonesia for instance bullying which is related to self disclosure and assertive behavior ${ }^{21}$, and bullying behavior with a child's moral understanding (Widiharto, 2011) ${ }^{49}$. Meanwhile, Djuwita, (2006) has conducted a survey of bullying in Indonesia, especially in Yogyakarta. In fact Yogyakarta, a city which is well known with the polite behavior, is the city with the highest case (70.06\%) when it is compared to Jakarta and Surabaya ${ }^{19}$. The survey was conducted in junior and senior high schools. When it is viewed from the psychosocial problems, Indonesian children and most children in Asia are strongly influenced by high collectivity. In this case, a social explanation on children problems is needed. Indonesia also has a very large ethnicity with different cultural customs and characteristics and these certainly affected to the type of bullying. Javanese children, for example, have different characters from other ethnic groups in Indonesia. 
The Javanese can be seen from a person or group of people with Javanese identity such as language, culture and traditions which are as the part of the Indonesian ${ }^{47}$. In addition, the characteristics of the Javanese are also obedient (setya tuhu), and not rebellious ${ }^{13,14}$. Abimanyu (2014) states that the Javanese is polite, refined, introvert and hard to be frankly. The Javanese always wanted to maintain harmony and avoid conflict so they tend to keep silent and not argue ${ }^{1}$. Some of the Javanese characteristics are narimo ing pandum (submissive with all what God disposes), gotong royong (mutual help each other) and ngajeni (respect).

Javanese culture has unique guidance for manners such as respecting others, being obedient and able to cooperate. Therefore, with the existence of aggressive behavior including bullying among Javanese ethnic vocational school students, it is necessary to know the forms of bullying among them since they live in a culture which does not allow them to be overt about their experience. They also should maintain harmonious interaction. And it is important to consider the bullying problem since they are now at the highest level of collectivity in ASEAN countries (Sittichai \& Smith, 2015) ${ }^{40}$.

Based on the above condition, the objectives of this research is to find out the bullying types among the Javanese ethnic of senior high school students. And the types of bullying discussed in this research refers Olweus (1993) statement in which he divided bullying into three types i.e. physical, verbal and psychological bullying.

\section{LITERATURE REVIEW}

\section{A. Bullying}

Bullying derives from the word "bull" in English which means a bull that likes to plow around (Sejiwa, 2008). The term is ultimately taken to describe a destructive act. Some countries, like Norway, Finland, Denmark, and Finland, mentions bullying with the term of mobbing. The original term comes from the UK, which mob usually refers to an anonymous and a large group of people and engages in violence. While Schwartz, Gorman, Nakamoto, \& Toblin (2005) called bullying with the term of victimization ${ }^{36}$. Buhs, Ladd, \& Herald(2006) adds the term peer exclusion and victimization to describe bullying ${ }^{6}$.

Tattum considers that bullying is a desire to harm and most of it must involve an imbalance of power i.e. the person or group being victimized which has no power and this happens repeatedly and they are unfairly attacked ${ }^{30}$. In contrast to other aggressive actions that involve attacks carried out in only one occasion and in a short time. Bullying usually occurs sustainably for long periods of time, so that the victim is constantly in anxious and intimidated state.

According to Sullivan(2011) bullying should also be distinguished from other aggressive actions or behaviors. The distinction is that it cannot be said to be bullying if the action is only to tease someone ${ }^{46}$. The fight occurs only once, and harsh acts or fights are not intended to cause destruction or damage either materially or mentally. Criminal acts such as attacks with sharp weapons, physical violence, serious acts to harm or kill, serious theft, and sexual harassment which are done only once cannot be called bullying. The main characteristic of bullying as stated by Olweus is the presence

of aggressive behavior that is repeated on other occasions and situations, and there is an imbalance of power between bullies and victims and the behavior causing painful effects on victims of bullying ${ }^{31}$.

\section{B. Bullying and Javanese Ethnic}

Ethnic-related bullying studies have been conducted by Seal \& Young (2003) but the study only distinguish the level of bullying of African American students with Caucasian students. While many have also studied bullying in relation to the states which found the difference of bullying definition, and bullying term in different country to describe bullying. Countries that became the object of research are European and American countries, countries in Australia and for Asia are represented by Taiwan and Japan. In Indonesia although there is already study about bullying but none of them discussed bullying associated with certain ethnic groups in Indonesia $^{10}$.

Ethnic groups in Indonesia have different cultural customs and characteristics. This certainly affects the types of bullying and bullying names in their respective ethnic languages. Javanese children, for example, have different characters from other ethnic groups in Indonesia. According to Endraswara (2012) in general the Javanese is more introvert in every way. In addition, the characteristics of the Javanese is also obedient (setya tuhu), not rejective and not rebellious ${ }^{12}$.Abimanyu(2014) adds that the Javanese as polite, refined, introvert and hard to be frankly. The Javanese always wanted to maintain harmony, and avoid conflict so they tend to be self-contained and not argue. The characteristic Javanese is narimo ing pandum (submissive with all what God disposes), gotong royong (mutual help) and ngajen (respect) older people. That character becomes a behavioral guiddance for Javanese in everyday life. Thus the Javanese who still hold the Javanese tradition will be very concerned about these teachings and will apply the Javanese philosophy in every act. It can be ascertained that the Javanese behavior in interacting with others will greatly appreciate people and do not put violence forward. This will certainly prevent the Javanese to become bully because some of the factors causes a person to become bully is to imitate the bullying of the surrounding environment and a pattern of nurture that does not show violence.

\section{METHOD}

\section{A. Sample}

The sample of this research was taken from 7 (seven) cities in Central Java and involves 12 High Schools. The sample cities are Semarang, Rembang, Pemalang, Juwana, Pati, Pekalongan and Ungaran. The samples of the school are vocational schools and public schools. The sample traits are active students enrolled in senior high school, both parents are Javanese ethnic and speak Javanese as their mother tongue. The selection of research participants was using purposive sampling technique. 
The participants were chosen by considering their characteristics based on the students' data at the school. Then the participants were interviewed briefly to check their parents' ethnicity and their mother tongue when communicating with parents and relatives and the use of Javanese as a colloquial language. Once the participants have gained in accordance with predetermined traits, the next step is to ask participants' willingness to engage in this research and ask participants to fill out an open questionnaire as the instrument of this study.

The data were collected using an open questionnaire. The researcher distributed 339 open questionnaires and after the selection there were 287 questionnaires that could be continued for analysis while 52 questionnaires were declared unanalyzed because they were inconsistent with the researchers' instructions and could not be verified to the participants.

\section{B. Analysis}

To analyze the open questionnaire data, the researcher used indigenous psychology approach. Kim and Berry define indigenous psychology as "the scientific study of human behavior or the mind that is native, that is not transported from other regions, and that is designed for its people". Indigenous psychology recommends examining the knowledge, skills and beliefs that people have about themselves and examine them in their natural context ${ }^{20}$. The data analysis was focused on the content and context of the study.

In this study, an open-ended questionnaire containing two statements that reveal bullying as well as the bullying sense. As it is stated by Olweus(1993) that participants repeatedly and often get negative behavior from one or more other students. This negative behavior results in the person suffering, injury or being uncomfortable with others. The second statement reveals the reason of the participant for the behavior he/she received. From the answers of these respondents, then they are grouped into specific themes related to bullying and if there is a dubious answer to the research team, then the team are pondering deeper by asking directly to the participants to get specific or clear answer. Specific themes are then incorporated into bullying types according to Olweus (2001).

\section{RESUlt AND FINDING}

The results showed that 287 respondents from high school students have been the highest victims of verbal bullying compared to physical bullying and psychological bullying. Respondents who experienced verbal bullying amounted to 207 or $72.13 \%$. Verbal bullying is often in the form of ridiculed, cheated, slandered, insulted, scolded, name-calling, and spreading rumors. Meanwhile, respondents who experienced physical bullying are as many as 42 respondents $(14.63 \%)$. The physical bullying experienced by the respondents was in the form of beaten, grabbed, and deprived of his property and sprayed with water. Psychological bullying is experienced by 28 respondents $(13.24 \%)$ in the form of exiled, belittled, got an intimidating view, not involved in the conversation, and being ignored. Complete data can be explained in Table 1 .

TABLE 1: TYPES OF BULLYING FROM JAVANESE ETHNIC STUDENTS

\begin{tabular}{|c|c|c|c|}
\hline Bullying Type & Percentage & Total & Description \\
\hline Verbal & $72,13 \%$ & 207 & $\begin{array}{l}\text { Ridiculed, lied } \\
\text { to, slandered }\end{array}$ \\
\hline Physical & $14,63 \%$ & 42 & $\begin{array}{l}\text { Beaten, } \\
\text { grabbed }\end{array}$ \\
\hline Psychological & $13,24 \%$ & 38 & $\begin{array}{r}\text { Exiled, } \\
\text { belittled }\end{array}$ \\
\hline
\end{tabular}

From the findings above, it can be explained that from seven cities that have been studied by involving 287 participants, verbal bullying is the highest cases. This verbal bullying has a profound impact on the subject. A research conducted by Albdour, Lewin, Kavanaugh, Hong, \& Wilson (2017) further explains that verbal bullying is the most painful type than any other type ${ }^{2}$. This is very interesting because Javanese culture does not allow someone to talk rudely and harm others. They also have to maintain harmony in human relations. Further explanation by Endraswara (2010) that Javanese society regulates its interactions through two principles namely the principle of harmony and the principle of respect. The two principles must be applied in all forms of interaction. Conflicts must be prevented. In the Javanese point of view, the principles of harmony must take precedence over positive law, but today's reality in society the priorities of alignment principles have shifted.

Based on the results of these studies, it can be explained that high school students who are in the seven areas, have experienced a shift in cultural values related to relations between humans. Javanese culture that should be full of gentleness values, away from violence and aggressiveness are not well internalized nowadays in the young generation. This shift in Javanese culture is also reinforced by Trikartono (2013) which states that the Javanese ethical values have faded, including the use of proper Javanese language ${ }^{48}$. Currently the use of Javanese stratified language by the younger generation is very rare.

In addition, the high rate of verbal bullying mostly occurred because verbal bullying is permissive by the environment and teachers. It is different from physical bullying such as hitting. Hitting is seen as a serious action and needed to get strict penalty from teachers or the society. This is in accordance with Mishna (2004) study which explains that teachers view non-physical aggression (verbal aggression) is not a serious thing because it does not seem a real impact so it is said not bullying. Teachers do little to intervene in the event of verbal bullying $^{22}$.

Based on the results of the research, it can be described that verbal bullying is the highest form that amounted $72.13 \%$ or experienced by as many as 207 subjects. The detail of verbal bullying that the subjects experienced were as follows: mocked by 119 participants, insulted by 45 participants, lied 14 participants, calling by name calling 9 participants, ordered 7 participants, scolded 5 participants, maligned 4 participants and shouted 4 participants. 
This is in line with the opinion of Bosworth, Espelage, \& Simon (1999) that most participants commit bullying in the form of mocking, nicknaming, threatening, socially laughing. Bullying with snaps has a low value compared to mocked or sarcastic $^{5}$. This is in accordance with the characteristics of the Javanese who conveys everything in disguise, subtle and meaningful way. Endraswara (2012) also affirms that Javanese is polite, refined, introvert and hard to be frankly. Abimanyu (2014) states that Javanese people tends to be disguised, thinking and behaving unopenly or tend to be symbolic His words are full of sanepa (symbolism) and many things which are not openly expressed or disguised in the hope of not offending the person to talk to.

Another form of bullying that is often experienced by the subject is physical bullying. It is experienced by 42 participants or about $14.63 \%$. The physical bullying experienced by the participants was in the form of beaten by 17 participants, dragged 12 participants, deprived of their belongings 7 participants and water sprayed 6 participants. Physical bullying is the most common type in countries such as Britain and Italy (Smorti, Menesini, \& Smith, 2003) ${ }^{44}$.

The form of psychological bullying experienced by 38 subjects or about $13.24 \%$. They are in the alienated form as many as 14 respondents, underestimated 11 respondents, got intimidating views 6 respondents, not involved in the conversation 4 respondents, and being ignored 3 respondents. This is in accordance with the research conducted in America that many subjects who become victims of bully because they are underestimated by their appearance or words ${ }^{25}$.

From the results of research above, the highest types of bullying is verbal bullying then followed by physical and psychological bullying. This is in accordance with the results of research from Smith, Cowie, Olafsson, \& Liefooghe(2002) which mentioned that in 14 countries, verbal bullying is the highest, then physical bullying and psychological bullying (social exclusion). In addition, according to the results of research conducted by Smorti, Menesini, \& Smith (2003) which mentions that the highest verbal bullying occurred in Japan and Portugal. Smith, Cowie, Olafsson, \& Liefooghe (2002) took the subject of students aged 8 and 14 years while in this study the participants are high school students aged 15-19 years who fall into the category of adolescents. Adolescents who engage in bullying have a low social skill when interacting with peer groups. Teenagers in their lives interact with many peer groups. Therefore, many adjustments should be made by a teenager. Carballo (Sarwono, 2002) mentions that self-adjustment should include: achieving maturity with independence, confidence and ability to face life, achieving acceptable position in society, developing conscience, responsibility, morality, and corresponding values with the environment and culture and solve real problems with his/her experience ${ }^{35}$. In interaction with their peers, teenagers also experience bullying. Ridicule, harassment, and attacks on peers can be very serious when children enter early adolescence ${ }^{18}$.

\section{Conclusion}

Based on the results of the research above, it can be concluded that the most dominant type of bullying in high school students in Java ethnics found in 7 (seven) cities in Central Java is verbal bullying. Verbal bullying becomes the most occurrences because of the shift of Javanese culture. Javanese culture that always keep harmony, speak ingentle words manifested in stratified Javanese kramainggil, kramamadya and ngoko is very rarely used in the Java community. In addition, the verbal bullying is not too visible than physical bullying so that teachers and the environment does not provide a serious intervention when verbal bullyin goccured. Verbal bullying is considered common behavior occurs in the Javanese society so it is also considered as a behavior that does not have a serious impact on victims of bullying.

For that reason there should be some efforts to decrease the number of verbal bullying on Javanese ethnic. These efforts include providing education and understanding to the young generation of Javanese ethnic to uphold the values of Javanese culture that uphold the manners. It is hoped that students will be able to keep themselves from being bullied or becoming bully. There is a need to provide teachers with understanding of the dangers of physical and psychological bullying through a variety of bullying prevention programs. That preventention can be done through school participation such as setting up anti-bullying programs, and creating psychological welfare schools for students to suppress or reduce bullying cases in schools.

The results of this study describes the types of bullying experienced by senior high school students in Javanese ethnic in Central Java. As it is described that Javanese ethnic has distinguish character which is different from other ethnic characteristics in Indonesia such as ethnic Batak or Dayak ethnic. For further research related to the types of bullying, it is also important to conduct research about bullying in the other ethnic group in Indonesia. It is important to be donein order to get various picture of bullying type in Indonesia.

\section{REFERENCES}

[1] Abimanyu, S. (2014). Babad Tanah Jawi. Jogjakarta: Laksana.

[2] Albdour, M., Lewin, L., Kavanaugh, K., Hong, J. S., \& Wilson, F. (2017). Arab American Adolescents' Perceived Stress and Bullying Experiences: A Qualitative Study. Western Journal of Nursing Research, 39(12), 1567-1588 https://doi.org/10.1177/0193945916678214

[3] Bosworth, K., Espelage, D. L., \& Simon, T. R. (1999). Factors Associated with Bullying Behavior in Middle School Students. The Journal of Early Adolescence, 19(3), 341-362. https://doi.org/10.1177/0272431699019003003

[4] Buhs, E. S., Ladd, G. W., \& Herald, S. L. (2006). Peer exclusion and victimization: Processes that mediate the relation between peer group rejection and children's classroom engagement and achievement? Journal of Educational Psychology, 98(1), 1-13. https://doi.org/10.1037/0022-0663.98.1.1

[5] Djuwita, R. (2006). "Kekerasan Tersembunyi di Sekolah": Aspek-aspek psikososial dari bullying. Retrieved June 25, 2008, from http://www.didplb.or.id

[6] Endraswara, S. (2010). Etika Hidup Orang Jawa, Pedoman Beretika dalam Menjalani Kehidupan Sehari-hari. Yogyakarta: Narasi.

[7] Endraswara, S. (2012). Falsafah Hidup Jawa, Menggali Mutiara Kebijakan dari Intisari Filsafat Kejawen. Jakarta: Cakrawala.

[8] Foshee, V. A., Reyes, H. L. M., Vivolo-Kantor, A., Basile, K., \& Chang, L.-Y. (2014). Bullying as a Longitudinal Predictor of Adolescent Dating Violence. Journal of Adolescent Health, 55, 439-444. 
[9] Mishna, F. (2004). A qualitative study of bullying from multiple perspectives. Children and Schools, 26(4), 234-247. https://doi.org/10.1093/cs/26.4.234

[10] Nansel, T. R., Craig, W., Overpeck, M. D., Saluja, G., \& Ruan, W. J. (2004). Cross-national Consistency in the Relationship Between Bullying Behaviors and Psychosocial Adjustment. Archives of Pediatrics \& Adolescent Medicine, 158(8), 730 https://doi.org/10.1001/archpedi.158.8.730

[11] Olweus, D. (1993). Bullying at School, What we konow and what we can do. Malden: Blackwell Publishing.

[12] Olweus, D. (2001). Bullying at school: Tackling the problem. OECD Observer, (225), 24-26. https://doi.org/10.1007/978-1-4757-9116-7_5

[13] Salmivalli, C., \& Voeten, M. (2004). Connections between attitudes, group norms, and behaviour in bullying situations. International Journal of Behavioral Development, 28(3), 246-258. https://doi.org/10.1080/01650250344000488

[14] Sanders, Cheryl E and Phye, G. D. (2004). Bullying, Implications for the Classroom. San Diego: Elsevier Academic Press.

[15] Sarwono, S. W. (2002). Psikologi Remaja. Jakarta: RajaGrafindo Persada.

[16] Schwartz, D., Gorman, A. H., Nakamoto, J., \& Toblin, R. L. (2005). Victimization in the Peer Group and Children's Academic Functioning. Journal of Educational Psychology, 97(3), 425-435. https://doi.org/10.1037/0022-0663.97.3.425

[17] Seal, D., \& Young, J. (2003). Bullying and Victimization: Prevalence and Relationship to Gender Level, Ethnicity, Self-Esteem, and Depression. Adolescence, 38(152), 735.

[18] Sejiwa. (2008). Bullying: Mengatasi Kekerasan di Sekolah dan Lingkungan Sekitar Anak. Jakarta: Grasindo.

[19] Sittichai, R., \& Smith, P. K. (2015). Bullying in South-East Asian Countries: A review. Aggression and Violent Behavior, 23, 22-35. https://doi.org/10.1016/j.avb.2015.06.002

[20] Skrzypiec, G., Slee, P., Murray-Harvey, R., \& Pereira, B. (2011). School bullying by one or more ways: Does it matter and how do students cope? School Psychology International, 32(3), 288-311. https://doi.org/10.1177/0143034311402308

[21] Smith, P. K., Cowie, H., Olafsson, R. R., \& Liefooghe, A. P. (2002). Definitions of bullying: A comparison of terms used, and age and gender differences, in a Fourteen-Country international comparison. Child Development, 73(4), 1119-1133. https://doi.org/10.1111/1467-8624.00461

[22] Smorti, A., Menesini, E., \& Smith, P. K. (2003). Parents' Definitions of Children' S Bullying. Journal of Cross-Cultural Psychology, 34(4), 417-432. https://doi.org/10.1177/0022022103254163

[23] Solberg, M. E., \& Olweus, D. (2003). Prevalence Estimation of School Bullying with the Olweus Bully/Victim Questionnaire. Aggressive Behavior, 29(3), 239-268. https://doi.org/10.1002/ab.10047

[24] Sullivan, K. (2011). The Anti-Bullying Handbook (Second Edi). London: SAGE Publications Ltd. Retrieved from https://books.google.co.id/books?id

[25] Trikartono, D. (2013). Pribadi dan Masyarakat Di Jawa Masa Kini. Yogyakarta: Jogja Global Media.

[26] Widiharto, C. A. (2011). Perilaku Bullying, Harga Diri dan Pemahaman Moral Anak. Metamorfosis. Retrieved from http://ejournal.ukrida.ac.id/ojs/index.php/MT/article/viewFile/772/78 2

\section{AUTHOR PROFILE}

I am Chr. Argo Widiharto, and I am affiliated with Airlangga University Surabaya, Indonesia. argo_widi@yahoo.com

I am Padmi Dhyah Yulianti, currently I am associated with Universitas PGRI Semarang, Indonesia.

I am Sri Wahyuni, currently I am affiliated with Universitas PGRI Semarang, Indonesia. 